\title{
Comprehension of Evidential Markers in Preschool Children with Language Delay
}

\author{
Young-Eun Lee ${ }^{\mathrm{a}}$, Soyoung Choi ${ }^{\mathrm{b}}$ \\ ${ }^{a}$ Department of Speech-Language Pathology, Graduate School, Dankook University, Yongin, Korea \\ ${ }^{b}$ Graduate School of Special Education, Dankook University, Yongin, Korea
}

Correspondence: Soyoung Choi, $\mathrm{PhD}$

Graduate School of Special Education, Dankook University, 152 Jukjeon-ro, Suji-gu, Yongin 16890, Korea

Tel: +82-31-8005-3813

Fax: +82-31-8021-7144

E-mail: syc529@dankook.ac.kr

Received: October 8, 2018

Revised: November 7, 2018

Accepted: November 21, 2018

This article is based on a part of the first author's master's thesis from Dankook University.

\begin{abstract}
Objectives: In various discourse situations, information gained through direct experience or through a third party can be expressed as 'evidential' through the use of grammar. To understand the concept of 'evidential' and the source of the information given, it is necessary to have linguistic and cognitive competence as well as an ability to understand the communicative context. The purpose of this study was to examine the ability of preschool children with language delay (LD) to comprehend the meaning of the evidential markers. Methods: Fifteen children (aged 4-6 years) in an LD group, 15 children matched by chronological age (CA), and 15 children match by language age (LA) participated in the study. The evidential tasks consisted of 32 sentences based on marking type (direct experience '- $\mathrm{e}$ ' and hearsay '-tay'), each combined with a picture of an information source condition ('seeing' or 'telling'). The participants then chose whether the evidential marker was suitable for the given information source condition. Results: The LD group showed significantly lower ability than the CA matched group, but there was no significant difference between the LD group and the LA matched group. Additionally, in each of the three groups, the participants performed better at identifying the direct experience conditions than the hearsay conditions. Conclusion: The reduced ability of LD children to comprehend evidential markers for information source conditions is understandable not only because of their limited semantic and morphological aspects, but also because they find it difficult to use inference to understand the source concepts or to reason the other person's perspective.
\end{abstract}

Keywords: Evidential markers, Language delay, Preschool children
지식의 습득은 직접적인 경험을 통해서 뿐만 아니라 매체나 타 인을 통한 간접적인 경로를 통해서도 이루어진다. 이에 지식의 종 류를 정보의 성격에 따라 직접 지식(direct knowledge)과 간접 지식 (indirect knowledge)으로 나누기도 하는데, 직접 지식은 화자가 직 접 목격하거나 경험함으로써 획득한 것이고, 간접 지식은 보고된 내용이나 단서에 기반한 추론을 통해 획득한 것을 말한다(Song, 2009). 학령전 아동의 언어발달 과정 또한 다양한 언어적 맥락에서 화자의 의도를 파악하고 많은 정보를 스스로 판단하여 선택해야 한다는 점에서 타인이 제공하는 정보의 확실성과 신뢰도를 가늠하 여 선별하는 능력이주요하게 작용할 수 있다(Harris, 2012).

전달된 정보의 확실성은 습득 방식과 출처에 대한 체계인 ‘증거 성(evidentiality)'을 바탕으로 판단 가능하며, 이는 어휘나 형태소
와 같은 언어적 표현을 빌어 제시될 수 있다(Choi, Jang, \& Lee, 2012; Davis, Potts, \& Speas, 2007; Papafragou, Li, Choi, \& Han, 2007). 어 휘에 의해 표시되는 정보출처 양식의 예는 "보았다, 짐작하다, 들었 다' 등으로 각각 화자의 정보가 직접 경험한 것인지, 어떤 단서를 근 거로 추측한 것인지, 또 다른 타인에게 전달받은 것인지를 알 수 있 게 한다. 영어나 독일어 등이 주로 어휘를 통해 선택적으로 증거성 을 표현하는 것에 비해, 한국어를 비롯한 일본어, 터키어, 투유카어, 티베트어, 불가리아어 등 세계 언어의 $25 \%$ 정도는 상대적으로 의무 적인 사용 특성을 갖는 문법형태소를 이용하여 정보의 출처를 표 시하는데, 이같은 형태론적 장치를 증거성 표지(evidential marker) 라 한다(Aikhenval'd, 2004). 한국어의 증거성 표지는 직접경험 (-더, -네), 간접보고(-대), 간접추론(-겠-, -나보-)의 세 가지 유형으로 
크게 나뉘며, 영 증거성 표지(zero evidential marker) '-어'도 확고한 주장 및 사실에 대한 진술에 사용된다는 점에서 직접 증거성 표지 라 할 수 있다(Song, 2009). 직접 표지는 화자가 목격하거나 내적 경 험을 통해 정보를 얻은 경우에 사용되며, 간접 표지는 제 3 자로부터 의 보고나 구체적인 근거에 기반한 추측을 뜻한다. 예를 들어 "밖 에 비가 오네."라는 문장은 화자가 직접 비가 오는 장면을 목격하였 음을 의미하고, "밖에 비가 온대."는 비가 온다는 정보를 타인의 보 고를 통해 화자가 알게 된 것을 의미한다. 증거성 표지를 바탕으로 정보의 출처를 이해하고 활용하는 능력은 새롭고 다양한 정보를 취합하여 습득하고 의사를 결정하는 데 중요한 역할을 담당한다. 이처럼 어휘나 증거성 표지와 같은 언어표현에 내포된 정보출처를 바탕으로 그 신뢰도와 확실성을 추론하여 판단하는 능력을 증거 성 추론(evidential reasoning)이라 칭하기도 한다(Choi, 2016). 연 구자들은 정보의 출처와 획득 방식에 따라 신뢰의 정도가 달라지 며, 간접적이고 추상적인 근거에 비해 직접적 경험과 사실에 근거한 것일수록 확실성이 높게 평가된다고 주장하면서 이같은 점이 인지 적 정보의 수집과 언어 개념을 체계화하는 과정에 영향을 미칠 수 있음을 강조하였다(Davis et al., 2007; Ünal \& Papafragou, 2018). 간접 경로에 비해 직접경험을 통한 정보가 보다 신뢰롭다는 것을 인식하는 것은 제 3 자에 의해 제공되는 정보를 접할 때 그 출처의 확실성을 비교하여 합리적이고 효율적으로 수용할만한 정보를 판 단하고 선택하는 데 도움이 될 수 있기 때문이다.

유사한 체계를 가진 한국, 일본, 터키에서 진행된 연구들은 증거 성 표지의 산출과 이해가 대체로 만 1세 6개월경 출현하여 만 4-5세 경 성숙에 이르는 것으로 보고하였다(Aksu-Koç, Ögel-Balaban, \& Alp, 2009; Choi, Jang, \& Lee, 2011; Choi \& Lee, 2012; Matsui, Yamamoto, \& McCagg, 2006; Papafragou et al., 2007). 예를 들어, 만 3-6세 아동에게 귓속말을 전해 듣는 사람과 상자 안을 직접 살펴보 는 사람을 제시하고 “상자에는 초콜릿이 들어있대."라는 말을 누가 하였을지 고르라고 하면 귓속말을 전해 들은 사람을 선택할 수 있 었다(Choi et al., 2011). 산출 측면을 보다 구체적으로 들여다보면, 직접경험을 나타내는 ‘-어'와 '-네’는 1 세 중반경 자발적 산출이 나 타나기 시작하여, 3 세 정도면 대부분의 아동들이 비교적 정확한 산출이 가능하지만, 간접보고를 나타내는 '-대'는 2 세 무렵에 자발 적 산출이 나타나고 3세가 되어야 성숙하기 시작하는 양상을 보였 다(Choi et al., 2011; Papafragou et al., 2007). 그에 반해, 간접추론 을 나타내는 문법 표지는 상대적으로 발달 시기가 느려 '-것 같다' 의 경우 4-5세경에야 자발적 산출이 관찰되었다(Choi \& Lee, 2012). 이해 측면에서는 직접경험 표지 '-어(네)'가 2세경에 발달을 시작하 는 반면, 간접보고 표지 '-대'와 간접추론 표지 '-것 같다'는 5-6세
이후 비교적 성숙한 수준에 도달하는 것으로 나타났다(Choi, Lee, \& Jang, 2010), 증거성 유형에 따라 산출과 이해 발달이 상이하게 관 찰되는 결과에 대하여 Ünal과 Papafragou (2018)는 간접적인 정보 를 전달하는 문법 표지 자체의 어려움이라기보다 정보의 출처가 되 는 타인의 관점을 이해하고 추론하는 과정에 기여하는 인지 및 협 응능력의 미성숙이 영향을 미칠 수 있음을 지적하였다. 본 연구는 증거성 표지의 발달 경로를 고려하여 연령 및 언어능력에 따른 차 이가 뚜렷이 나타날 것으로 추정되는 직접경험 표지 '-어'와 간접보 고 표지 '-대'를 중심으로 학령전기 언어발달지체 아동이 정보출처 에 따라 증거성 표지를 적절히 이해할 수 있는지 알아보았다.

초기 언어를 습득하는 아동들은 다양한 어휘와 문법형태소를 습득하면서 구문적 복잡성과 화용 기술이 함께 향상되어가는데, 특히 학령전기는 영유아기에 습득된 기본적인 언어 기술을 보다 구 체적으로 발달시켜감과 동시에 다가올 학령기에 성공적으로 적응 하는 데 필요한 언어능력을 키워가야 하는 중요한 시기이다(Park \& Lee, 2009). 그러나 일반아동에 비해 상대적으로 언어발달 속도 가 느린 언어발달지체 아동은 언어영역 전반에 걸쳐 어려움을 나타 낼 수 있으며 특히 문법적인 발달이 취약한 것으로 알려져 있다 (Leonard, 1998). 이에 영어권 연구자들은 언어장애 아동을 진단하 기 위한 임상적 표지로 문법형태소의 중요성을 언급하기도 하였다 (Rice \& Wexler, 1996). 국내에서 진행된 연구들 역시 언어발달지체 아동들이 문법형태소를 비롯한 문법 규칙의 습득과 사용에서 두 드러진 문제를 보임을 보고하고 있다(Hwang, 2003; Jo, Choi, \& Hwang, 2014; Kim \& Pae, 2002). 그 외에도 언어발달지체 아동들 이 가진 의미론적(Lee \& Kim, 2003), 구문론적(Han, Hwang, \& Jeong, 2016), 화용론적(Lee \& Seok, 2009) 측면의 결함은 다양한 담화 상황에서 유입되는 정보의 출처를 파악하는 과정에 영향을 미칠 수 있을 것이다. 증거성 이해의 성숙을 위해서는 문법형태소 로 표현된 증거성 표지의 의미적 화용적 측면을 내재된 개념의 표 상에 적절하게 연결하는 능력이 요구되며, 연령 증가에 따른 언어 적, 인지적 능력의 향상은 정보출처의 탐지를 비롯한 증거성 표지 이해 및 산출능력과 밀접한 관련이 있다고 알려져 있다(Choi et al., 2010). 즉, 증거성 표지는 정보의 출처를 표시하는 단순한 문법적 기 능을 넘어 화자의 의도에 대한 추론을 포함하여 정보의 확실성을 판단하는 능력을 파악할 수 있는 단서가 되리라고 본다. 그에 따라 본 연구는 문법적 표지가 발달하면서 구문 구조가 확장되는 4 세부 터 6세까지의 언어발달지체 아동을 대상으로 정보출처에 따른 증 거성 표지의 이해능력을 살펴보고, 언어연령을 일치시킨 일반아동 및 생활연령을 일치시킨 일반아동과 비교하였다.

현재까지 진행된 증거성 표지에 관한 연구들은 대부분 일반아동 
의 발달 관점에서 이루어졌으며, 학령전 언어발달지체 아동을 대상 으로 증거성 표지 유형에 따른 차이를 체계적으로 검증한 연구는 극히 드물다. Choi 등(2012)은 3-6세 일반아동에게 주인공인 인형 캐릭터가 선물받은 내용을 (1) 직접 열어서, (2) 타인이 말해주어서, (3) 추측을 통해서 확인하는 과정을 동영상으로 제시한 뒤 서로 다 른 증거성 표지를 포함한 문장을 들려주고 맞는 진술을 고르도록 하였다. 연구 결과 직접경험(-네), 간접보고(-대), 간접추론(-것 같 다) 표지 모두 연령 증가와 함께 발달하는 추이를 보이면서 5 세를 기점으로 급격하게 이해가 증가하는 양상이 나타났다. 그러나 증거 성 표지 간의 차이와 연령과 표지의 상호작용은 통계적으로 유의 하지 않았는데, 조건별 시행 수가 2개에 불과하여 일반화하기에는 제약이 있다. 최근 Song (2018)은 만 5-6세 단순언어장애 아동과 일 반아동을 대상으로 직접경험과 간접추론에 해당하는 증거성 표지 ('-네'/'것 같다') 및 증거성 어휘('보다'‘생각하다') 각각을 사용한 문장을 들려주고 어느 진술이 더 확실한 정보인지 판단하도록 한 결과, 단순언어장애 아동이 일반아동에 비해 증거성 이해가 어려 움을 보고하였다. 다만 동일한 그림 자극을 증거성 어휘와 표지 조 건에 중복 제시한 점이 과제 수행에 영향을 미쳤을 수 있으며, 정확 한 진술을 한 인물카드를 선택하는 방식은 증거성 표지에 대한 이 해라기보다는 정보 확실성에 대한 판단을 요하기에 연구결과의 해 석이 제한적이다. 또한 언어 수준에 대한 통제 집단을 구성하지 않 은 점과 증거성 유형(직접경험/간접추론)에 따른 차이는 검증하지 못하였다는 점에서 추가적인 연구가 필요한 실정이다.

한편, 학령전 아동의 증거성 표지 이해를 측정한 연구들은 보통 문장에 사용된 문법 표지의 출처를 판단하거나 정보의 출처에 문 법 표지가 적절하게 사용되었는지 판단하는 방식을 취해왔다. 이 때 실험자 혹은 동영상을 통해 정보출처에 관한 상황 정보를 제시 하여 인물의 상태를 추론해야 하거나 두 명의 등장인물 혹은 두 개 의 발화 중 택일하는 과정을 거침으로 인해 어린 연령의 참가자가 절차를 숙지하기 어렵고 증거성 표지 처리 외의 부담이 가중되는 경향을 보였다(Choi et al., 2011; Choi et al., 2010; Papafragou et al., 2007). 이에 Lee와 Lee (2016)는 학령기 아동 대상의 연구에서 사지 선다형의 문장읽기방식을 통해 난이도 조정을 시도하였으나, 수행 목표를 전달하는 과정에서 마찬가지의 어려움이 있었음을 보고하 였다. 이에 본 연구의 과제는 화자와 청자가 고정된 상태에서 정보 출처(직접경험/간접보고)를 그림으로 제시하고 증거성 표지(-어/대)를 포함한 문장을 들려준 뒤 일치 여부를 판단하도록 하여 참가 자의 부담과 절차의 난이도를 제고하였다.

정리하자면 본 연구는 (1) 언어발달지체 아동과 언어연령 및 생 활연령 각각을 일치시킨 통제집단 간에 비언어적(non-linguistic)으
로 표현된 정보출처 조건(직접경험 '보다')간접보고 '듣다')을 바탕 으로 증거성 표지(직접경험 '-어'/간접보고 '-대')를 이해하는 능력 에 차이가 있는지 알아보고, (2) 학령전 아동의 증거성 표지 이해능 력이 연령 및 인지, 언어능력과 어떠한 상관관계를 갖는지 확인하 고자 하였다. 이같은 시도는 학령전 언어발달지체 아동이 정보출처 를 파악하여 보다 정확하게 언어적 맥락을 이해하고 적절한 문법 표지의 활용을 통해 의사소통할 수 있도록 하는 중재에 의미 있는 기초를 마련할 것이다.

\section{연구방법}

\section{연구대상}

본 연구의 참가자는 서울과 경기 지역에 거주 중인 생활연령 4 세 11 개월-6세 6개월의 언어발달지체 아동 15 명(남 12 , 여 3)과 언어연 령을 일치시킨 일반아동 15 명(남 10 , 여 5), 생활연령을 일치시킨 일 반아동 15 명(남 8, 여 7)으로 총 45 명이었다. 4 세경에 전반적인 증거 성 표지의 이해가 발달하기 시작하고, 6 세 무렵 간접보고에 해당하 는 표지인 '대'가 비교적 성숙에 이른다는 선행연구 결과를 참조하 여 4-6세 아동을 대상으로 진행하였다(Choi et al., 2011; Papafragou et al., 2007).

언어발달지체 아동 집단은 (1) 취학전 아동의 수용언어 및 표현 언어 척도(Preschool Receptive-Expressive Language Scale, PRES; Kim, Sung, \& Lee, 2003) 검사 결과 통합언어연령이 생활연령에 비 해 1년 이상 지체되어 있고, (2) 한국 웩슬러 유아지능검사(KoreanWechsler Preschool and Primary Scale of Intelligence, K-WPPSI; Park, Kwak, \& Park, 1996)의 동작성 지능 85 이상에 해당하며, (3) 부모 또는 교사에 의해 청각 및 시각 등의 감각장애와 정서 및 행동 적 문제가 없는 것으로 보고된 아동들로 선정하였다. 언어연령일치 일반아동 집단은 (1) 언어발달지체 아동 집단 평균 언어연령의 \pm 6 개월 이내에 해당하는 아동으로, (2) PRES 검사 결과 통합언어연령 이 생활연령의 1년 이내에 속하고, (3) K-WPPSI의 동작성 지능 85 이상에 해당하며, (4) 부모 또는 교사에 의해 청각 및 시각 등의 감 각장애와 정서 및 행동적 문제가 없는 것으로 보고된 아동들로 선 정하였다. 생활연령일치 일반아동 집단은 (1) 언어발달지체 아동 집 단 평균 생활연령의 \pm 6 개월 이내에 해당하는 아동으로, (2) PRES 검사 결과 통합언어연령이 생활연령의 1년 이내에 속하고, (3) KWPPSI의 동작성 지능 85 이상에 해당하며, (4) 부모 또는 교사에 의해 청각 및 시각 등의 감각장애와 정서 및 행동적 문제가 없는 것 으로 보고된 아동들로 선정하였다.

세 집단이 적절하게 구성되었는지 확인하고자 언어발달지체 아 
Table 1. Participants' characteristics

\begin{tabular}{lccc}
\hline & $L D(N=15)$ & $L A(N=15)$ & $C A(N=15)$ \\
\hline Age $(\mathrm{mo})$ & $66.67(6.66)$ & $46.53(7.49)$ & $67.60(4.71)$ \\
Performance $10^{\mathrm{a}}$ & $114.53(16.81)$ & $115.53(13.19)$ & $122.80(13.17)$ \\
Language age $^{\mathrm{b}}(\mathrm{mo})$ & $48.93(9.82)$ & $52.67(5.70)$ & $72.47(4.79)$ \\
\hline
\end{tabular}

Values are presented as mean (SD).

$\mathrm{LD}=$ children with language delay; $\mathrm{LA}=$ language age-matched children; $C A=$ chronological age-matched children.

a Korean-Wechsler Preschool and Primary Scale of Intelligence (Park, Kwak, \& Park, 1996), 'Preschool Receptive-Expressive Language Scale (Kim, Sung, \& Lee, 2003).

동 집단과 두 통제 집단에 대한 독립표본 $t$-검정(independent sample $t$-test)을 실시하였다. 언어발달지체 아동과 생활연령일치 일반 아동 간 생활연령에 유의한 차이가 없는 것으로 나타났으며 $(t=.443$, $p>.05)$, 언어발달지체 아동과 언어연령일치 일반아동 간 PRES 통 합연령에서도 유의미한 차이가 없었다 $(t=1.273, p>.05)$. 집단별 연 구참가자 정보의 상세는 Table 1과 같다.

\section{연구도구}

본 연구의 과제는 정보출처(직접경험 '보다'/간접보고 '듣다')를 바탕으로 증거성 표지(-어/-대)를 이해하는 능력을 알아보기 위한 것으로 Papafragou 등(2007)과 Choi 등(2011, 2012)의 연구를 참조 하여 제작하였다. 과제의 형식은 정보의 출처를 표현한 그림을 본 뒤 증거성 표지가 포함된 문장을 듣고 일치를 판단하도록 하였다. 증거성 표지 이해 과제 문항의 예시는 Appendix 1에 제시하였다.

먼저 아래와 같은 과정을 거쳐 증거성 표지를 포함한 문장을 만 들었다. 문장의 기본 구조는 언어발달지체 유무에 상관없이 언어연 령 4-5세 아동이 [행위자-장소], [행위자-공존자], [행위자-대상]의 논항구조의 문장을 자유롭게 산출 가능하였다고 보고한 연구(Han et al., 2016)를 참고하여 ‘주어-목적어-서술어’ 형식으로 일치시켜 통사적 길이 및 복잡성을 통제하였으며, 서술어 어절의 음절수는 3 음절, 목적어 어절의 음절수는 1-3음절로 구성하였다. 사건 및 상황 을 표현할 과제의 서술어는 초기 언어 습득 단계의 학령전 아동을 대상으로 한 선행연구들(Han et al., 2016; Lee, Chang, Choi, \& Lee, 2009; Won \& Hwang, 2005)에 공통적으로 사용된 동사 목록과 등 급별 국어교육용 어휘(Kim, 2003)의 1-2등급 목록을 토대로 추상 적이지 않고 구체적인 동작의 이미지 구현이 가능한 40 개의 동사로 선별하였다. 목적격 명사는 등급별 국어교육용 어휘(Kim, 2003)의 1-2등급 중 1-3음절의 일반 사물 및 신체 이름으로 구성하였으며, 앞서 선정된 동사와 의미 연결이 자연스럽게 선정하였다. 행위자인 남아와 화자인 여아를 지칭하는 이름은 참가자가 들었을 때 친숙 성이 높도록 학령전기 동화책에 주로 나오는 이름 중 ‘민수’와 ‘유미'
로 하였다. 이러한 기준에 의해 제작된 총 40 개 문항에 대하여 어휘 의 난이도 및 문장 의미의 적절성을 언어병리학전공 교수 1 인과 1 차 검토 후 수정 보완하였다. 추가적인 내용타당도 검증을 위해 언 어병리학 석사과정에 재학 중인 2 급 언어치료사 5 명과 생활연령 4-5세 아동을 양육하고 있는 일반성인 2명에게 Likert식 5점 척도 (1점 $=$ 매우 부적절, 5 점 $=$ 매우 적절) 평정을 받아 평균 2.5 미만의 문항은 제외하였다. 최종 선정된 36개 문장은 음성합성 시스템인 Text to Speech (TTS) 프로그램(Smart AAC 태블릿 문자형 ver. 1.0.8) 을 사용하여 화자인 여아음성으로 변환하였다.

다음으로 36 개의 문장에 해당하는 그림을 제작하였다. 이때 직 접경험 조건은 화자(유미)가 타인(민수)의 행동을 옆에서 바라보고 있는 것으로 표현하였으며, 간접보고 조건은 타인(민수)이 화자(유 미)에게 귓속말하는 모습으로 표현하였다. 1차 제작단계에서 간접 보고 조건의 경우 행동이 직접적으로 묘사되지 않는다는 점을 고 려하여 귓속말의 말풍선 내에 상황 그림을 추가하는 방식으로 인 지적 부담을 줄이고자 시도하였으나, 예비실험 결과 부자연스러운 그림의 형태와 아동들이 오히려 들려주는 문장에 집중하지 못하 는 양상이 지적되어 수정하였다. 최종적으로 제작된 그림이 문장 을 적절하게 구현하였는지 확인하기 위해 언어병리학전공 교수 1 인 의 검토를 거쳤으며, 언어병리학 석사전공 5 명과 일반성인 3 명에게 그림을 제시하고 문장으로 표현하도록 하여 부적절한 항목에 대해 서는 행위의 명료성과 그림크기 등을 보완하였다.

전체 문항은 연습 시행 4 개와 32 개의 본 시행으로 이루어져 있으 며, 정보출처 조건별(직접경험/간접보고)로 각 16 개 문항이 할당되 었다. 각 조건 중 절반은 정보출처와 일치하는 증거성 표지 문장을 제시하여 ‘네’ 응답이 정반응이고(보다-어, 듣다-대), 나머지 절반 은 정보출처와 불일치하는 증거성 표지 문장을 제시하여 '아니오' 응답이 정반응이 되도록 하였다(보다-대, 듣다-어). 이때 한 조건 내 에 유의어나 반의어와 같이 의미적으로 중첩되는 어휘나 발음이 유사한 어휘가 있을 경우 어린 연령의 참가자가 혼동할 여지가 있 어 서로 다른 조건에 배치되도록 조정하였다.

\section{연구절차}

연구는 아동의 가정을 방문하여 개별적으로 실시되었으며, 연구 자와 아동이 나란히 앉아 컴퓨터 화면을 바라보는 상태로 진행하 였다. 연구자는 아동에게 2 명의 등장인물 그림을 보여주며 각각의 인물은 ‘민수’와 ‘유미’라고 소개한 후, 유미가 민수가 한 일을 직접 보고 아동에게 알려줄 수도 있고 민수의 말을 듣고 아동에게 알려 줄 수도 있다고 설명하여 화자와 정보출처 조건 및 증거성 표지의 사용을 인지하도록 하였다. 또한 유미는 가끔 틀리게 말할 수도 있 
으니 유미가 민수를 직접 봤는지, 보지 않고 이야기를 전해 들었는 지 잘 듣고 판단해야 함을 안내하였다. 연구과제는 노트북(Microsoft Surface PRO 4 i5/13inch)을 사용하여 파워포인트(PowerPoint 2013)의 슬라이드 쇼로 제시되었으며, 아동은 4 개의 연습 시행을 거친 뒤본 과제 32 문항을 수행하였다.

증거성 표지 이해 과제 절차의 상세는 다음과 같다. 정보출처 조 건(직접경험, 간접보고)에 대한 그림이 4초 동안 나타난 뒤 화면이 전환되면 화자인 유미와 말풍선이 나타나고 증거성 표지(-어/-대) 를 포함한 문장이 스피커를 통해 제시되었다. 문장 제시가 끝나면 화면에 'O', 'X'가 주어지고 참가자는 그림으로 표현된 정보출처와 음성으로 제공된 증거성 표지가 일치하는지 판단하여 구두로 답하 거나 화면을 가리켜 반응하도록 하였다. 아동의 반응은 연구자가 즉시 별도 검사지에 기록하였다. 예를 들어, 유미가 옆에서 민수가 책을 찢고 있는 장면을 직접 보고 있는 그림(직접경험 조건)이 나온 후 아동에게 '-어(직접경험 증거성 표지)'를 사용한 “민수가 책을 찢 었어.”를 들려주면, 그림의 정보출처와 음성의 증거성 표지가 일치 하기 때문에 ‘O'를 가리켜야 한다. 그와 달리 민수가 유미에게 귓속 말을 하는 그림(간접보고 조건)이 나온 후 아동에게 "민수가 책을 읽었어."를 들려주면 그림의 정보출처와 음성의 증거성 표지가 일 치하지 않기 때문에 ' $\mathrm{X}$ '를 가리켜야 한다(Appendix 2). 과제 문항의 정답은 'O', 'X'가 같은 비율로 제시되었고, 동일한 정보출처 조건 및 증거성 표지가 3 회 이상 연속되지 않도록 유사무선배열하였다.

연습 시행 시 아동이 과제 이해에 어려움을 보이면 그림 자극의 행동을 주시하도록 다시 설명하여 수행 목표와 절차를 숙지하도록 하였다. 본 시행에서 ‘모르겠다' 또는 '무응답(10초 이상 반응이 없 는 상태)'에 해당할 경우에는 다시 들려줄지 물어본 뒤 아동의 동의 하면 연구자가 구두로 1 회에 한해 문장을 다시 들려주었다. 전체 절 차는 약 20-30분 정도가 소요되었다.

\section{자료분석}

본 연구는 증거성 표지 이해를 살펴보기 위해 정보출처 조건(직 접경험 '보다'간접보고 '듣다')이 표현된 그림과 증거성 표지(직접 경험 '-어'/간접보고 '-대')를 포함한 문장의 일치 여부를 판단하는 과제를 실시하였다. 아동이 제시된 그림의 정보출처와 증거성 표지 문장의 일치성을 올바르게 선택하면 특정 증거성 표지가 나타내는 정보습득 방식을 적절히 이해한 것으로 간주하였다. 총 32 개 문항 에 대하여 정반응한 경우 1 점, 오반응일 경우 0 점을 부여하였으며, 직접경험 조건과 간접보고 조건에서 획득할 수 있는 최대 점수는 각 16 점이었다. 이때 집단별 15 명의 참가자가 수행한 총 시행 720 개 중 '모르겠다' 또는 '무응답'의 반응을 보인 빈도는 언어발달지체
아동 집단에서 4 회, 언어연령일치 일반아동 집단에서 5 회, 생활연 령일치 일반아동 집단에서 2 회로 각기 다른 참가자에게서 나타났 으며 $(4.58 \%)$, 그중 4 건은 과제 문장을 다시 듣고 적절한 반응이 가 능하였다.

기록된 점수에 대하여 세 집단(언어발달지체 아동, 언어연령일치 일반아동, 생활연령일치 일반아동) 간에 정보출처 조건(직접경험, 간접보고)에 따른 증거성 표지 이해의 차이가 유의미한지 알아보 고자 반복측정된 혼합 이원분산분석(repeated measure two-way mixed ANOVA)과 Tukey 사후검정을 실시하였다. 더불어 학령전 아동의 증거성 표지 이해 과제 수행과 연령, 언어능력(PRES 점수) 및 인지기능(IQ 지수)의 관련성을 확인하기 위해 Pearson 적률상 관계수를 구하였다.

\section{연구결과}

\section{세 집단 간 정보출처 조건(직접경험, 간접보고)에 따른 증거성 표지 이해}

언어발달지체 아동 집단과 언어연령을 일치시킨 일반아동 집단 및 생활연령을 일치시킨 일반아동 집단 간에 증거성 표지 이해 과 제 수행의 차이를 보이는지 살펴보았다. 세 집단의 정보출처 조건별 정반응 점수 평균과 표준편차는 Table 2 와 같다. 집단(3)과 정보출 처 조건(2)을 변인으로 분석한 결과, 집단의 주효과 $\left(F_{(2,42)}=28.488\right.$, $p<.001)$ 와 정보출처 조건의 주효과 $\left(F_{(1,42)}=42.166, p<.001\right)$ 가 유 의한 것으로 나타났다. 세 집단 간 차이에 대한 Tukey 사후검정을 실시하였을 때, 언어발달지체 아동과 생활연령일치 아동 $(p<.001)$, 언어연령일치 아동과 생활연령일치 아동 $(p<.001)$ 간에 통계적으 로 유의미한 차이가 있었으며, 언어발달지체 아동과 언어연령일치 아동 간의 차이는 유의하지 않았다. 즉, 언어발달지체 아동은 생활 연령일치 일반아동에 비해서는 낮은 정반응 점수를 나타냈으나 언 어연령일치 일반아동과는 유사한 수준의 수행을 보였다. 반면, 세 집단은 공통적으로 직접경험 조건에 비해 간접보고 조건의 이해가 어려운 것으로 관찰되었으며, 집단과 정보출처 조건 간 상호작용효 과는 통계적으로 유의한 수준에 도달하지 못하였다 $\left(F_{(2,42)}=.972\right.$, $p>$.05).

Table 2. Number of correct responses according to the groups and conditions

\begin{tabular}{lrrr}
\hline & $L D(N=15)$ & $L A(N=15)$ & $C A(N=15)$ \\
\hline Direct experience & $8.40(1.59)$ & $9.47(1.12)$ & $12.00(2.56)$ \\
Hearsay & $6.47(1.59)$ & $6.67(1.75)$ & $10.27(1.94)$ \\
Total & $14.87(2.41)$ & $16.14(1.84)$ & $22.27(3.93)$ \\
\hline
\end{tabular}

Values are presented as mean (SD). 
Table 3. Result of correlation analysis $(N=45)$

\begin{tabular}{llcc}
\hline & Age & Performance IO & PRES \\
\hline Performance $10^{\mathrm{a}}$ & .210 & - & - \\
PRES & $.438^{* *}$ & .229 & - \\
Direct experience & .208 & .054 & $.592^{* *}$ \\
Hearsay & $.396^{* *}$ & .263 & $.692^{* *}$
\end{tabular}

PRES = Preschool Receptive-Expressive Language Scale (Kim, Sung, \& Lee, 2003). aKorean-Wechsler Preschool and Primary Scale of Intelligence (Park, Kwak, \& Park, 1996). ${ }^{* *} p<.01$.

\section{증거성 표지 이해와 관련 변인들의 상관}

다음으로 학령전 아동의 증거성 표지 이해 과제의 수행이 연령, 언어능력(PRES 점수) 및 인지기능(IQ 지수)과 관련이 있는지 알아 보기 위하여 Pearson 적률상관분석을 실시하였다. Table 3에서 보여 지듯이 연령과 언어능력 $(r=.438, p<.01)$ 및 간접보고 조건 $(r=.396$, $p<.01)$ 간에 유의한 정적 상관관계가 나타나, 학령전 아동의 경우 연령이 증가할수록 언어검사 점수와 간접보고 표지의 이해력이 높 은 것으로 분석되었다. 한편, 인지기능과 언어검사 점수 및 증거성 표지 이해 과제 점수 간에는 유의한 상관이 나타나지 않은 것에 반 해, 언어능력은 직접경험 조건 $(r=.592, p<.01)$ 및 간접보고 조건 $(r=.692, p<.01)$ 과 유의미하게 높은 정적 상관을 보임으로써 언어 검사 수행이 우수한 아동이 정보출처와 증거성 표지를 이해하는 능력 또한 높은 것으로 나타났다.

\section{만 3-6세 일반아동의 연령에 따른 증거성 표지 이해 발달}

만 3-6세에 해당하는 두 통제 집단의 연령 분포가 만 3세 7명, 만 4세 8명, 만 5세 8명, 만 6세 7명으로 제한적인 수이기는 하나 비교 적 균등하게 구성됨에 따라 추가적으로 참가자 30 명 자료에 대한 반응정확도(\%)를 산출하여 증거성 표지 이해의 발달 추이를 가늠 해보았다(Figure 1).

연령(4)과 정보출처 조건(2)을 변인으로 분산분석을 실시한 결 과, 연령의 주효과 $\left(F_{(3,26)}=9.390, p<.001\right)$ 와 정보출처 조건의 주효 과 $\left(F_{(1,26)}=29.618, p<.001\right)$ 가 유의한 것으로 나타났다. 연령 집단 간 차이에 대하여 Tukey 사후검정을 실시한 결과, 만 3세와 만 4세 집단 간 및 만 5세와 만 6세 집단 간의 차이는 유의하지 않았으나 ( $p>.05)$, 만 3세와 만 5세, 만 3 세와 만 6세, 만 4세와 만 5세, 만 4세 와 만 6세 집단 간의 차이는 통계적으로 유의미하여(각 $p<.01)$ 만 3-4세에 비해 만 5-6세 집단의 증거성 표지 이해 수행이 높은 것으 로 분석되었다. 모든 연령대에서 직접경험 조건에 비해 간접보고 조 건의 수행이 어려웠으나, 직접경험 표지가 간접보고 표지보다 상대 적으로 이른 시기에 발달하는 경향을 관찰할 수 있었다. 연령과 정

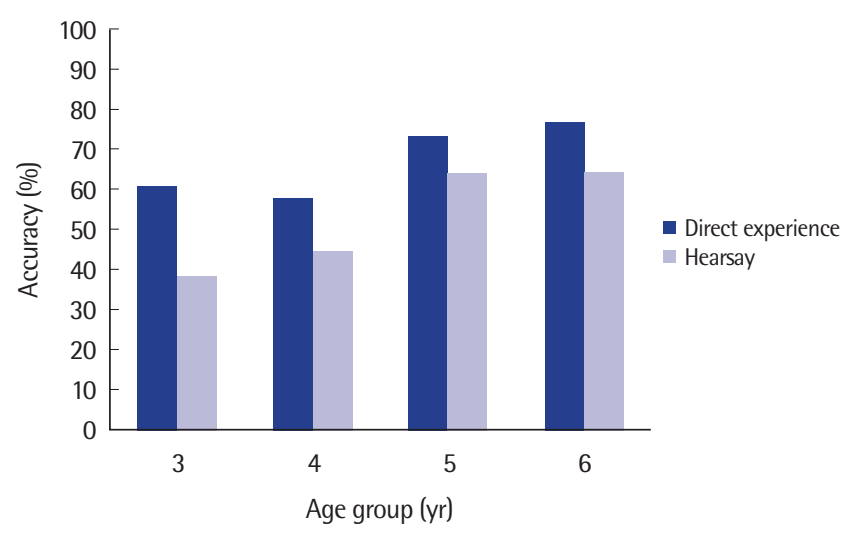

Figure 1. Correct percentage of evidential tasks by groups and the conditions.

보출처 조건의 상호작용효과는 유의하지 않았다.

\section{논의 및 결론}

본 연구는 언어발달지체 아동을 대상으로 증거성 표지 이해능력 을 측정하여 언어연령 및 생활연령 각각을 일치시킨 일반아동 집단 과 차이가 있는지 살펴보았다. 이를 위해 정보출처 조건(직접경험 '보다', 간접보고 '듣다’)이 표현된 그림을 제시하고 증거성 표지(직 접경험 '-어', 간접보고 '-대’)를 포함한 문장을 들려준 뒤 그 일치를 판단하도록 하였다. 주요 연구결과에 대하여 언어-인지 발달 측면 과의 관련성을 중심으로 고찰하였다.

첫째, 언어발달지체 아동 집단은 생활연령일치아동 집단에 비해 낮은 수행을 보였으나, 언어연령일치아동 집단과의 차이는 통계적 으로 유의미하지 않았다. 언어발달지체 아동은 일반아동보다 어휘 습득 및 사용, 구문적 이해와 표현과 같은 전반적인 언어능력에서 지체를 보인다고 알려져 있다(Lee \& Kim, 2003; Owens, 2013). 단 순언어장애아동 대상의 연구에서도 또래에 비해 문법형태소의 사 용 빈도가 낮고 문법형태소의 실수가 잦으며(Kim \& Pae, 2002), 문 법 판단능력이 지체되어 있는 것으로 관찰되었다(Jeong \& Hwang, 2007). 본 연구결과는 언어발달지체 아동들의 경우 정보의 출처를 파악하기 위해 활용되는 문법형태소인 증거성 표지 이해의 발달 또 한 지연되어 있음을 시사하였다.

둘째, 세 집단 아동들은 공통적으로 직접경험 조건에 비해 간접 보고 조건에서 수행의 어려움을 보였다. 기존 연구들에서 알려진 바와 같이 직접경험을 나타내는 증거성 표지 '-네/-어'가 간접보고 를 나타내는 증거성 표지 ‘-대’보다 이른 시기에 성숙함에 따라(Choi et al., 2011, 2012; Choi et al., 2010; Papafragou et al., 2007) 상대적 으로 안정된 수행이 가능하였던 것으로 보이며, 유사한 증거성 표 
지 체제를 사용하는 터키어, 일본어에서도 같은 양상이 보고된 바 있다(Aksu-Koç et al., 2009; Matsui et al., 2006). 한편, 집단과 정보 출처 조건 간 상호작용이 통계적으로 유의하지 않음에 따라 언어 발달지체 아동의 증거성 표지 이해 특성은 또래 아동에 비해 지연 되지만 질적으로 일탈된 양상을 보이지는 않았다. 이는 언어발달지 체 아동들의 언어발달 추이가 대체로 일반아동들과 유사한 패턴을 가지나, 전반적인 습득 및 산출이 지연되며 늦은 시기까지 오류가 빈번하게 나타나는 특성을 보인다는 견해와 맥을 같이한다(Kim, 2014).

셋째, 학령전 아동의 경우 연령이 증가하면서 언어능력과 증거성 표지의 이해가 증가하는 경향을 보였으며, 연령 요인은 간접보고 조건의 수행과 유의한 상관 관계를 나타낸 반면 언어검사 점수는 두 유형의 정보출처 조건 모두의 수행과 유의미한 정적 상관이 있 는 것으로 분석되었다. 더불어 만 3-6세에 해당하는 일반아동 집단 을 통해 연령에 따른 증거성 이해 발달의 추이를 가늠해보았을 때 만 3-4세 집단에 비해 만 5-6세 집단에서 증거성 표지의 적절성을 판단하는 정확도가 유의하게 높았으며, 직접경험 표지가 간접보고 표지보다 상대적으로 이른 시기에 발달하는 경향을 보였다.

증거성 표지가 전달하는 정보의 출처 및 그에 따라 달라지는 정 보의 확실성을 적절히 이해하기 위해서는 직접경험과 간접경험을 구분할 수 있는 정보출처 탐지(source monitoring) 능력이나 이를 활용하기 위한 작업기억, 정보제공자의 증언에 대한 진위를 판별하 여 허위 진술을 무시하고 객관적 증거나 직접경험을 근거로 판단하 는 문제해결능력 등 여러 인지 기제가 밀접하게 작용한다고 알려져 있다(Choi et al., 2012; Choi \& Lee, 2012; Choi et al., 2010; Jaswal, Croft, Setia, \& Cole, 2010; Matsui \& Fitneva, 2009; Papafragou et al., 2007). Choi 등(2010)에 따르면 '보다' 또는 '듣다'와 같이 어휘적 으로 표시된 정보출처에 대해서는 만 3-4세경에도 정보의 확실성 에 대한 판단이 가능하였으나, 어휘가 아닌 문법적 증거성 표지를 바탕으로 정보 확실성을 판단하는 증거성 추론 능력은 만 6세경까 지도 우연 수준에 그쳤다. 연구자들은 증거성 표지를 토대로 정보 의 출처 및 정보가 습득된 상태, 정보 제공자의 관점과 신뢰도 등을 추출하는 과정에 논리적으로 추론하는 사고 능력이 영향을 미칠 가능성을 들어 같은 시기에 발달하는 인지 언어 요인들의 변화를 함께 검토할 필요가 있음을 지적하였다.

다른 한편으로 정보습득 과정에 대한 자신과 타인의 인식 상태 에 대한 이해가 수반된다는 점에서 마음이론과의 관련성이 제기되 기도 하였다(Choi et al., 2011; Lee \& Lee, 2016; Matsui \& Fitneva, 2009; Papafragou et al., 2007). 정보출처에 따른 확실성의 위계는 3-4세경에 형성되지만 다양한 증거성 표지를 화용적으로 활용하
는 일은 화자의 미묘한 의사소통 의도에 대한 추론까지 결부되는 까닭에 상대적으로 복잡하며, 이같은 화용적 기능으로 인해 어휘 나 문법적 측면에서 증거성을 획득하는 것에 비해 학령전 아동에게 어려움을 초래하게 된다는 것이다(Papafragou \& Musolino, 2003). 실제 단순언어장애 아동을 대상으로 한 연구들에서 생활연령일치 집단에 비해 마음이론 과제 수행의 어려움이 보고되어 있고(Kim \& Kim, 2006; Lee \& Ahn, 2016), 화자와 청자 간에 진실이라고 가 정하고 공유하는 전제를 추론하는 능력에서도 언어연령일치 집단 과 유사한 수준을 보인다(Kim, Hwang, \& Lim, 2012).

선행연구들과 본 연구결과를 종합해 보면 언어발달이 지체된 아 동은 더 어린 생활연령의 아동과 유사한 언어-인지적 발달 수준을 가진 것으로 추정되며, 증거성 표지를 문법적으로 이해하는 것뿐 아니라 상대방 발언의 출처를 추론하는 능력도 성숙하지 않은 상 태로 여겨진다. 추후 학령전 언어발달지체 아동들의 증거성 표지 이해와 인지 및 화용능력을 포괄적으로 측정하여 구체적인 관련성 을 밝히는 연구를 시도해야 할 것으로 보이며, 이때 다음 사항들을 염두에 둘 것을 제언한다. 첫째, 기존 연구들에서 사용된 기법들이 다수의 등장인물과 진술에 대한 처리를 요함으로써 어린 연령의 참 가자가 수행하기 어려웠던 점을 감안하여 본 연구는 정보출처를 비 구어적 자극인 그림으로 제시하고 하나의 진술과의 일치성을 판단 하도록 과제와 절차의 난이도를 단순화하였다. 그러나 만 3세 미만 아동에게 예비실험을 실시하였을 때에는 여전히 수행 목표를 이해 하지 못하는 모습을 보였다. 또한 직접경험 조건과의 명확한 구분 을 위해 타인에 의해 제공되는 간접보고 조건의 경우 상황 그림을 직접적으로 제시하지 않았다는 점에서 아동이 체감하는 난이도가 다소 상이하였을 가능성이 있다. 더불어 정보출처 자극을 균등한 수준으로 노출하고자 그림이 사라진 뒤 증거성 표지 문장을 들려 주었기에 그림을 기억하면서 일치성을 판단해야 하는 부담이 일부 존재하였다. 앞서 언급한 증거성 표지에 따른 정보 확실성 판단 수 행과작업기억의 관련성(Choi et al., 2010) 및 언어발달이 지체된 아 동들이 또래에 비해 제한된 언어성 작업기억을 보인 점(Kweon \& $\mathrm{Kim}, 2004 ; \mathrm{Oh} \& \mathrm{Goo}, 2008)$ 등을 고려할 때 연령에 적합한 과제 구현 방식에 대한 고찰이 요구된다. 둘째, 본 연구는 직접경험과 간 접보고 유형을 조건으로 각 표지를 대표하는 '-어', '-대'의 이해 측 면을 알아보았으나, 이외에도 화자의 내적 경험(예: 아프다) 혹은 간 접적 단서에 대한 추론(예: - 것 같다, -나봐)과 같은 다양한 위계와 형태의 증거성 표지에서 언어발달에 따른 차이를 탐색해야 할 것이 다. 더욱이 일부 연구에서 간접 표지의 이해가 만 6세경에도 성인 수준에 도달하지 못하며(Choi et al., 2011), 그중에서도 간접추론의 경우 4학년경까지도 꾸준히 발달한다는 결과가(Lee \& Lee, 2016) 
보고되어 있어 학령전기와 학령기를 아우르는 기초 자료의 누적이 필요하다.

증거성 체계에 대한 이해는 언어적 자극으로부터 추상적인 정보 출처의 개념을 추출하는 것뿐 아니라 그에 따른 다양한 정보의 신 뢰성을 추론하는 과정을 동반한다는 점에서 언어와 개념/의도 체 계 간의 관계를 파악하는 연구에 기여할 수 있다. 또한 학령전 언어 발달지체 아동이 겪는 문법적, 화용적 습득의 지연이 학령기로 접 어들면서 읽기 및 학습, 또래 관계에까지 영향을 미칠 수 있다는 점 에서(Matsui \& Fitneva, 2009) 증거성 표지를 바탕으로 정보의 출 처를 이해하고 활용하는 언어 기술의 중재를 실시한다면 가치 있는 정보를 효율적으로 선택하고 의사소통 상황을 심도 있게 파악할 수 있는 인지적 강점을 제공할 수 있을 것이다. 같은 견지에서 $\mathrm{Pa}-$ pafragou 등(2007)은 언어 학습자가 증거성 표지의 의미를 해석하 기 위해 화자의 발화에 내재된 의미와 언어 환경에 존재하는 공통 성(commonality)을 추출해내는 과정이 어려움을 유발하기 때문 에 문법형태소와 같은 언어적 요소를 사용하여 명시적으로 증거성 을 표시하는 것이 정보출처의 개념을 분별하여 이해하는 데 도움 이 된다고 제안하였다. 본 연구는 학령전 언어발달지체 아동들이 동일 생활연령의 또래 집단과 비교하여 정보출처 조건에 따른 증거 성 표지 이해에 어려움을 보이나, 직접 표지를 간접 표지에 비해 상 대적으로 잘 이해함에 따라 증거성 위계에 대한 개념은 발달하고 있음을 경험적으로 확인하였다는 데 의의가 있으며, 이를 토대로 다양한 후속 연구와 중재 방안의 모색이 이어지기를 기대한다.

\section{REFERENCES}

Aikhenvald, A. Y. (2004). Evidentiality. Oxford: Oxford University Press.

Aksu-Koç, A., Ögel-Balaban, H., \& Alp, İ. E. (2009). Evidentials and source knowledge in Turkish. New Directions for Child and Adolescent Development, 2009, 13-28.

Choi, Y. (2016). The development of selective trust and evidential reasoning: a literature review. Korean Journal of Developmental Psychology, 29, 63-82.

Choi, Y., \& Lee, H. I. (2012). Developmental pattern of evidential markers and related verbs: analyses of natural production \& input language. Korean Journal of Developmental Psychology, 25, 129-150.

Choi, Y., Jang, N. Y., \& Lee, H. I. (2011). Development of evidentiality: production, comprehension and it's relation to theory of mind. Korean Journal of Developmental Psychology, 24, 93-108.

Choi, Y., Jang, N. Y., \& Lee, H. I. (2012). Factors affection Korean preschoolers' evidential reasoning: trust in testimony and understanding of eviden- tial markers. Korean Journal of Developmental Psychology, 25, 135-152.

Choi, Y., Lee, H. I., \& Jang, N. Y. (2010). Development of understanding the relationship between information source and certainty. Korean Journal of Developmental Psychology, 23, 109-124.

Davis, C., Potts, C., \& Speas, M. (2007). The pragmatic values of evidential sentences. Proceedings of the 17th Semantics and Linguistic Theory Conference, Storrs, CT, 71-88.

Han, Y. H., Hwang, M., \& Jeong, M. (2016). Sentence production ability depending on argument numbers in preschool children with language delay. Journal of Speech-Language \& Hearing Disorders, 25, 187-198.

Harris, P. L. (2012). Trusting what you're told: how children learn from others. Cambridge, MA: The Belknap Press of Harvard University Press.

Hwang, M. (2003). The production of grammatical morphemes of Korean children with developmental language impairments. Speech Science, 10, 47-64.

Jaswal, V. K., Croft, A. C., Setia, A. R., \& Cole, C. A. (2010). Young children have a specific, highly robust bias to trust testimony. Psychological Science, 21, 1541-1547.

Jeong, M., \& Hwang, M. (2007). Grammaticality judgments in children with specific language impairment: detection of erroneous case-markers. Korean Journal of Communication \& Disorders, 12, 587-606.

Jo, M., Choi, S., \& Hwang, M. (2014). The comprehension and production of tense markings in language delayed children and typically developing children. Phonetics and Speech Sciences, 6, 123-131.

Kim, J. M., \& Kim, Y. T. (2006). Pragmatic comprehension of school-aged children with specific language impairment: ability to use common ground. Korean Journal of Communication \& Disorders, 11, 90-105.

Kim, K. (2003). Vocabularies for different levels of Korean education. Seoul: Pagijung.

Kim, M., Hwang, M., \& Lim, J. A. (2012). Drawing Inferences from the presuppositions of sentences in children with specific language impairment (SLI). Journal of Speech \& Hearing Disorders, 21, 1-15.

Kim, S. Y., \& Pae, S. Y. (2002). The use of grammatical morphemes of Korean children with language impairment. Speech Sciences, 9, 77-91.

Kim, Y. T. (2014). Assessment and Treatment of Language Disorders in Children (2nd ed.). Seoul: Hakjisa.

Kim, Y. T., Sung, T. J., \& Lee, Y. K. (2003). Preschool receptive-expressive language scale (PRES). Seoul: Seoul Community Rehabilitation Center.

Kweon, Y. H., \& Kim, Y. W. (2004). Relation of verbal working memory to sentence comprehension in children with specific language impairment. 
Korean Journal of Communication \& Disorders, 9, 33-48.

Lee, E. K., \& Seok, D. I. (2009). Comparing the metaphoric ability between language delayed children and normal children. Journal of Speech \& Hearing Disorders, 18, 27-39.

Lee, H. R., Chang, Y. K., Choi, Y. L., \& Lee, S. B. (2009). Lexical acquisition of Korean infants: characteristics of early expressive vocabulary. Journal of Speech \& Hearing Disorders, 18, 65-80.

Lee, J. H., \& Lee, H. R. (2016). The relationship between evidentiality development and theory of mind in school-aged children. Communication Sciences \& Disorders, 21, 206-216.

Lee, S. Y., \& Ahn, S. W. (2016). The characteristics of children specific language impairment in theory of mind of emotional understanding. The Journal of Special Children Education, 18, 173-201.

Lee, Y., \& Kim, Y. T. (2003). Word (noun and verb) production in children with specific language impairment. Korean Journal of Communication \& Disorders, 8, 1-19.

Leonard, L. B. (1998). Children with specific language impairment. Cambridge, MA: MIT Press.

Matsui, T., \& Fitneva, S. A. (2009). Knowing how we know: evidentiality and cognitive development. New Directions for Child and Adolescent Development, 2009, 1-11.

Matsui, T., Yamamoto, T., \& McCagg, P. (2006). On the role of language in children's early understanding of others as epistemic beings. Cognitive Development, 21, 158-173.

Oh, K. M., \& Goo, S. Y. (2008). Inhibitory control, working memory, and language ability in 4-5 year-old normal children and children with devel- opmental language delay. Korean Journal of Communication \& Disorders, 13, 263-281.

Papafragou, A., \& Musolino, J. (2003). Scalar implicatures: experiments at the semantics-pragmatics interface. Cognition, 86, 253-282.

Papafragou, A., Li, P., Choi, Y., \& Han, C. H. (2007). Evidentiality in language and cognition. Cognition, 103, 253-299.

Park, H., Kwak, K., \& Park, K. (1996). Korean-Wechsler Preschool and Primary Scale of Intelligence (K-WPPSI). Seoul: Seoul Community Rehabilitation Center.

Park, S. H., \& Lee, H. R. (2009). Research trends in preschool childhood language impairment during the last 10 years. Korean Journal of Communication \& Disorders, 14, 1-13.

Rice, M. L., \& Wexler, K. (1996). Toward tense as a clinical marker of specific language impairment in English-speaking children. Journal of Speech, Language, and Hearing Research, 39, 1239-1257.

Song, J. M. (2009). Epistemic modality and evidentiality. Korean Linguistics, 44, 27-53.

Song, M. E. (2018). Characteristics of comprehending evidential markers and words for Korean preschool children with specific language impairment (Master's thesis). Catholic University of Pusan, Busan, Korea.

Ünal, E., \& Papafragou, A. (2018). Relations between language and cognition: evidentiality and sources of knowledge. Topics in Cognitive Science, 1-21. DOI: $10.1111 /$ tops.12355.

Won, H. M., \& Hwang, M. (2005). The comprehension and production of tense markings in 3-to 5-year old Korean children. Speech Sciences, 12, 183-195. 
Appendix 1. 증거성 표지 이해 과제 문항 예시

\begin{tabular}{|c|c|c|c|}
\hline 정보출처 조건 & 사건 그림 & 제시 문장 & 정반응 \\
\hline \multirow[t]{6}{*}{ 직접경험(-어) } & 유미가 양말을 신고 있는 민수를 보고 있음 & 민수가 양말을 신었어 & Y \\
\hline & 유미가 이를 닦고 있는 민수를 보고 있음 & 민수가 이를 닦았어 & Y \\
\hline & 유미가 공을 던지고 있는 민수를 보고 있음 & 민수가 공을 던졌어 & Y \\
\hline & 유미가 사진을 찍고 있는 민수를 보고 있음 & 민수가 사진을 찍었대 & $\mathrm{N}$ \\
\hline & 유미가 물을 쏟고 있는 민수를 보고 있음 & 민수가 물을 쏟았대 & $\mathrm{N}$ \\
\hline & 유미가 픙선을 불고 있는 민수를 보고 있음 & 민수가 풍선을 불었대 & $\mathrm{N}$ \\
\hline \multirow[t]{6}{*}{ 간접보고(-대) } & 민수가 유미에게 귓속말을 하고 있음 & 민수가 바지를 입었대 & Y \\
\hline & 민수가 유미에게 귓속말을 하고 있음 & 민수가 과자를 먹었대 & Y \\
\hline & 민수가 유미에게 귓속말을 하고 있음 & 민수가 머리를 빗었대 & Y \\
\hline & 민수가 유미에게 귓속말을 하고 있음 & 민수가 창문을 닫았어 & N \\
\hline & 민수가 유미에게 귓속말을 하고 있음 & 민수가 아기를 만졌어 & $\mathrm{N}$ \\
\hline & 민수가 유미에게 귓속말을 하고 있음 & 민수가 노래를 불렀어 & $\mathrm{N}$ \\
\hline
\end{tabular}

Appendix 2. 증거성 표지 이해 과제 절차 예시

- 직접경험 조건
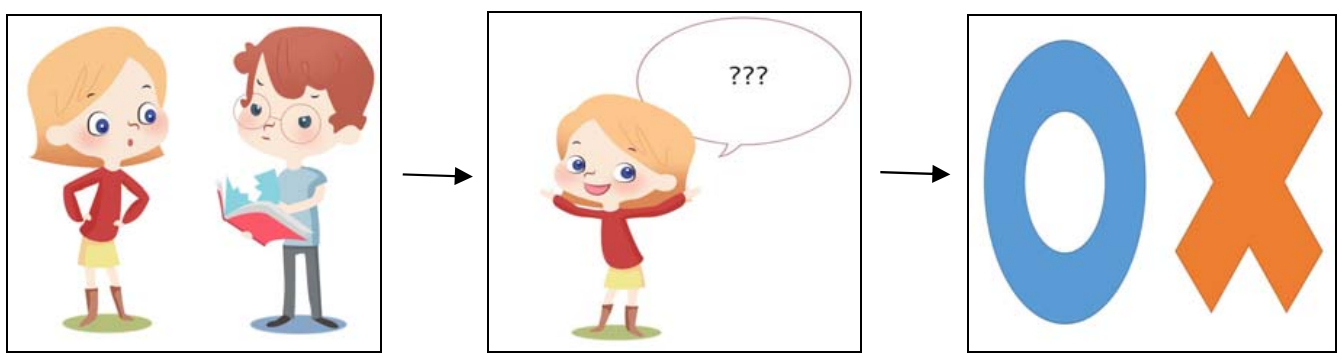

- 간접보고 조건
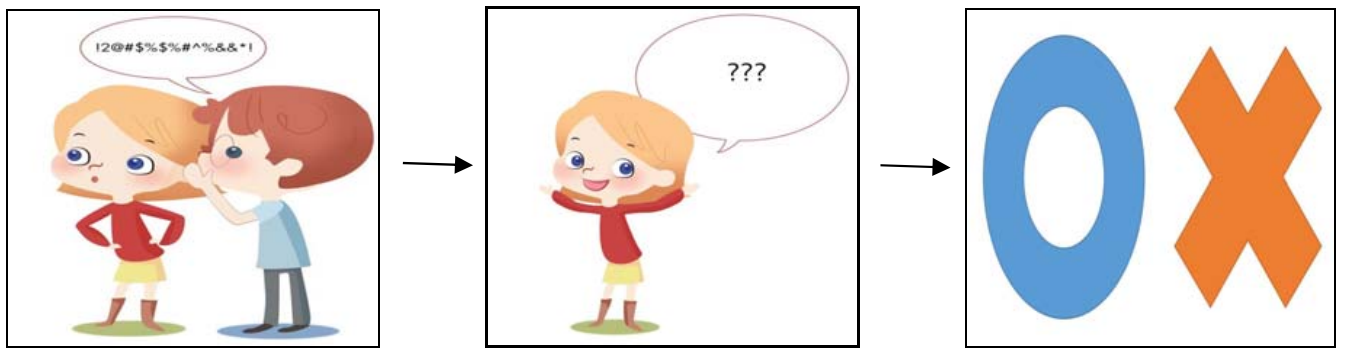


\section{국문초록}

\section{학령전 언어발달지체 아동의 증거성 표지 이해 특성}

이영은'(학생, 제1저자) · 최소영'(교수, 교신저자)

'단국대학교 일반대학원 언어병리학과, ${ }^{2}$ 단국대학교 특수교육대학원

배경 및 목적: 의사소통 상황의 다양한 정보들은 직접적인 경험이나 타인의 보고를 통해 얻어질 수 있으며, 이같은 정보의 출처를 증거 성 표지와 통합하여 이해하는 과정에는 적절한 언어인지 능력이 요구된다. 본 연구는 언어발달지체 아동을 대상으로 정보의 출처를 나 타내는 문법형태소인 증거성 표지에 대한 이해 능력을 살펴보고자 하였다. 방법: 본 연구의 참가자는 4-6세 언어발달지체 아동 15명, 생 활연령을 일치시킨 일반아동 15 명, 언어연령을 일치시킨 일반아동 15 명이었다. 증거성 표지 이해 과제는 총 32 문항으로 구성되었으며, 정보출처 조건(직접경험 ‘보다'간접보고 ‘듣다')이 표현된 그림과 증거성 표지(직접경험 '-어'간접보고 '대’)가 포함된 문장을 제시하고 일치성을 판단하도록 하였다. 결과: 언어발달지체 아동은 생활연령일치 아동 집단에 비해 낮은 증거성 표지 이해 수행을 보였으나, 언어 연령일치 아동과의 차이는 통계적으로 유의미하지 않았다. 반면 세 집단은 공통적으로 직접경험 조건에 비해 간접보고 조건에서 어려 움을 보였다. 한편, 증거성 표지 이해 능력은 언어 능력과 유의미한 상관이 있는 것으로 나타났다. 논의 및 결론: 본 연구 결과를 통해 언 어발달지체 아동들이 증거성 표지를 기반으로 정보의 출처를 파악하고 이해하는 과정에서 또래 일반아동에 비해 지연된 발달 양상을 보임을 확인하였다. 이같은 어려움은 언어의 의미와 형태를 넘어 정보출처와 타인의 관점을 추론하는 능력과 관련되어 있을 수 있다.

핵심어: 증거성 표지, 언어발달지체, 학령전 아동

본 논문은 제 1 저자의 석사학위논문을 수정·보완한 것임.

\section{참고문헌}

권유현, 김영욱(2004). 단순언어장애 아동의 언어성 작업기억과 문장이해간의 관계. 언어청각장애연구, 9, 33-48. 김광해(2003). 등급별 국어교육용 어휘. 서울: 박이정.

김미리내, 황민아, 임종아(2012). 단순언어장애아동의 전제의미 추론. 언어치료연구, 21, 1-15.

김수영, 배소영(2002). 언어발달지체아동의 문법형태소 사용 특성. 음성과학, 9, 77-91.

김영태(2014). 아동언어장애의 진단 및 치료(제2판). 서울: 학지사.

김영태, 성태제, 이윤경(2003). 취학전 아동의 수용언어 및 표현언어 척도(PRES). 서울: 서울장애인종합복지관.

김정미, 김영태(2006). 학령기 단순언어장애아동의 화용적 이해: 상호지식의 이용능력을 중심으로. 언어청각장애연구, 11, 90-105.

박소현, 이희란(2009). 학령전기 언어장애 연구의 최근 동향. 언어청각장애연구, 14, 1-13.

박혜원, 곽금주, 박광배(1997). 한국-웩슬러 유아지능검사(K-WPPSI). 서울: 도서출판 특수교육.

송명은(2018). 학령전 단순언어장애 아동의 증거성 표지와 어휘 이해 특성. 부산가톨릭대학교 대학원 석사학위논문.

송재목(2009). 인식양태와 증거성. 한국어학, 44, 27-53.

오경민, 구세영(2008). 4, 5 세 정상발달아동과 언어발달장애아동의 억제조절 및 작업기억과 언어능력과의 관계. 언어청각장애연구, 13, 263-281.

원혜미, 황민아(2005). 3-5세 아동의 시제어미 이해와 산출의 정확성. 음성과학, 12, 183-195.

이상연, 안성우(2016). 단순언어장애 아동의 마음이론과 정서이해 특성: 일반아동과 4세, 6세 연령 간의 비교를 통해. 특수아동교육연구, 18, 173-201. 이윤경, 김영태(2003). 단순언어장애 아동들의 낱말산출 능력: 명사와 동사를 중심으로. 언어청각장애연구, 8, 1-19.

이은경, 석동일(2009). 언어발달지체 아동과 일반 아동의 은유능력 비교. 언어치료연구, 18, 27-39.

이지현, 이희란(2016). 학령기 아동의 문법 표지 발달과 마음이론 간의 관계: 경험과 추론을 중심으로. Communication Sciences \& Disorders, 21,

206-216. 
이희란, 장유경, 최유리, 이승복(2009). 한국 아동의 어휘 습득: 초기 표현 어휘의 특징. 언어치료연구, 18, 65-80.

정미란, 황민아(2007). 단순언어장애 아동의 문법성 판단: 조사 오류를 중심으로. 언어청각장애연구, 12, 587-606.

조미옥, 최소영, 황민아(2014). 언어발달지체아동과 일반아동의 시제 표지 이해 및 산출 특성. 말소리와음성과학, 6, 123-131.

최영은(2016). 의심의 기술 발달: 선택적 신뢰와 증거성 추론. 한국심리학회지: 발달, 29, 63-82.

최영은, 이화인(2012). 증거성표지 및 관련 어휘 발달 양상: 자발적 산출과 입력언어의 분석. 한국심리학회지: 발달, 25, 129-150.

최영은, 이화인, 장나영(2010). 정보 원천 표현에 따른 정보 확실성 이해의 발달. 한국심리학회지: 발달, 23, 109-124.

최영은, 장나영, 이화인(2011). 증거성표지의 이해, 산출과 마음이론발달의 관련성 연구. 한국심리학회지: 발달, 24, 93-108.

최영은, 장나영, 이화인(2012). 학령전기 아동의 증언판별, 증거성표지 이해와 정보확실성 판단 능력 발달. 한국심리학회지: 발달, 25, 135-152.

한영희, 황민아, 정미란(2016). 학령전기 언어발달지체아동의 용언의 논항 수에 따른 문항 산출 능력. 언어치료연구, 25, 187-198.

황민아(2003). 언어발달장애 아동의 문법형태소 산출. 음성과학, 10, 47-64. 